\section{ЗАРУБІЖНИЙ ДОСВІД ДЕРЖАВНОГО РЕГУЛЮВАННЯ ДІЯЛЬНОСТІ ПАСАЖИРСЬКОГО АВТОМОБІЛЬНОГО ТРАНСПОРТУ}

\section{FOREIGN EXPERIENCE OF STATE REGULATION OF ROAD PASSENGER TRANSPORT}

\author{
ПЕТРЕНКО О. М., \\ доктор технічних наук, доцент, \\ доцент кафедри електричного \\ транспорту, Харківський \\ національний університет міського \\ господарства ім. О. М. Бекетова
}

\author{
PETRENKO O., \\ Doctor of Engineering, Associate \\ Professor, Department of \\ Electrical Transport, $\mathbf{O}$. \\ M. Beketov National University \\ of Urban Economy in Kharkiv
}

В статті розглянуто особливості зарубіжного досвіду державного регулювання діяльності пасажирського автомобільного транспорту. Виявлено, щзо вигоди від реформ $i$ скасування регулюючого впливу набагато зростають в тих випадках, якщо вдається створити $i$ підтримувати сильну конкурениію. 3'ясовано, щзо у світі реформуються всі види транспорту, але особлива увага приділясться зараз міському та приміському транспорту як лідерам дотацій.

Ключові слова: державне регулювання, пасажирський автомобільний транспорт, транспортна інфраструктура.

B cтатье рассмотрены особенности зарубежного опыта государственного регулирования деятельности пассажирского автомобильного транспорта. Выявлено, что выгоды от реформ $и$ отмены регулирующего влияния намного возрастают в тех случаях, если удается создать и поддерживать сильную конкуренцию. Выяснено, что в мире реформируются все виды транспорта, но особое внимание уделяется сейчас городском и пригородном транспорта как лидерам дотаичй.

Ключевые слова: государственное регулирование, пассажирский автомобильный транспорт, транспортная инфраструктура.

The article deals with the features of foreign experience of state regulation of passenger road transport. It is revealed that the benefits of reforms and the abolition of regulatory influence are much greater in cases where it is possible to create and maintain strong competition. It was found that all modes of transport are being reformed in the world, but special attention is now paid to urban and suburban transport as the leaders of subsidies.

Keywords: state regulation, passenger road transport, transport infrastructure.

Постановка проблеми. У результаті сьогоднішніх трансформацій у сфері українського пасажирського автомобільного транспорту, особливий інтерес 
представляє досвід державного регулювання транспорту країн, що вже пройшли через суттєві реформи міського транспорту США, Великобританія, Нідерланди, Німеччина, Нова Зеландія і т. д. В названих та інших країнах світу проблеми підвищення ефективності державного та муніципального регулювання пасажирського транспорту перебувають у центрі суспільної уваги. Одним 3 найбільш обговорюваних способів вирішення цих проблем $є$ лібералізація транспортної галузі, звільнення іiі від державного регулювання, що обмежує сферу ринку і вільного підприємництва. Популярність ринкового підходу багато в чому обумовлена тим, що державне регулювання транспорту породжує набагато серйозніші проблеми, ніж ті, для вирішення яких воно вводилося.

Аналіз останніх досліджень $i$ публікацій. Проблеми державного регулювання діяльності пасажирського автомобільного транспорту висвітлені в працях як зарубіжних, так і вітчизняних вчених. Вагомий внесок у дослідження особливостей впливу держави на транспортну систему зробили такі вчені, О. Амоша [1], М. Білик [10], Н. Доброва [2], Т. Затонацька [3], В. Єресов [8], М. Казакова [4], В. Кучменко [5], О. Лановий [8], О. Мороз [6], М. Нечепуренко [2], М. Осипова [2], В. Поліщук [8], Б. Симпсон [9], О. Філіппова [1], С. Цимбал [10], Я. Шевчук [11] та ін. Однак, незважаючи на численні дослідження, недостатньо висвітленими залишаються шляхи вирішення економічних проблем формування та розвитку системи державного регулювання діяльності пасажирського автомобільного транспорту в Україні.

Метою статmі $є$ визначення особливостей зарубіжного досвіду державного регулювання пасажирського автомобільного транспорту та виявлення певних засобів, які доцільно використовувати при формуванні системи державного регулювання даним процесом в Україні.

Виклад основного матеріалу. У першу чергу слід назвати дефіцит транспортних послуг, що виникає через те, що держава прагне зробити ціну цих послуг нижче, ніж ціна ринкової рівноваги. Встановлений державою тариф, як правило, настільки низький, що попит на транспортні послуги перевищує пропозицію. Особливим випадком є нульовий тариф, з яким ми стикаємося, користуючись безкоштовними автошляхами. Дефіцит транспортних послуг проявляється в перевантаженості транспортної інфраструктури, нестачі транспортних засобів, чергах, пробках. Це явище існує майже у всіх промислово розвинутих країнах.

Дефіцит транспортних послуг може поєднуватися і з високими тарифами, якщо встановлена державна монополія. Для встановлення монополії достатньо, щоб уряд заборонив або істотно обмежив можливість входу нових постачальників послуг на ті чи інші ринки. Особливо часто державна монополія встановлюється на транспортну інфраструктуру. Така ситуація типова для Японії та країн Свропейського Союзу. Пом'якшеною формою державної монополії є жорстке ліцензування і обмеження входу на ринок транспортних послуг.

Зустрічаються й інші види адміністративного регулювання, що насилу піддаються формальному опису та кількісному обліку, через різноманітність форм, та екзотичність вироблених ефектів.

Одним з таких прикладів є обмеження на рух автомобільного транспорту, встановлені в Лондоні навесні 2003 р. В Лондоні, крім дорожнього податку і 
податку на паливо, введена плата за в'їзд автотранспорту в центр міста. У результаті, щодня в центр міста в'їжджає приблизно на 100 тисяч автомобілів менше колишнього, що, за деякими оцінками, на 10\% скоротило обсяг продажів в магазинах центрального Лондона, з відповідними наслідками для зайнятості [8, c. 299]. У наземному транспорті, наприклад, у таксі, історично у більшості країн склалася стандартна система ліцензування таксистів, полягає не у встановленні якихось жорстких вимог до кваліфікації водіїв або стану машин, а в простому обмеження кількості виданих ліцензій. Нові ліцензії отримати неможливо.

В Ірландії з 1978 р. число таксистів було обмежено числом ліцензій, i тільки в 2000 р. ці обмеження були зняті. Аналогічне регулювання 3 подальшим дерегулюванням здійснено в деяких містах США та Австралії [1, с. 180].

Приватизація пасажирських автотранспортних підприємств із скасуванням державного регулювання тарифів і допуску на ринок проведена в Коломбо (ШріЛанка), Сантьяго (Чилі) і Великобританії (вся країна, крім Лондона). Проте через відмінності місцевих умов і характеру самих реформ зіставити їх результати досить складно [5, с. 80]. У Коломбо і Сантьяго реформи призвели до значного збільшення обсягу транспортного обслуговування населення, у великій Британії загальний пробіг парку виріс, але при цьому пасажирооборот зменшився.

У Коломбо вартість проїзду після проведення перетворень практично не збільшилася, у Великобританії ж вона помітно зросла (в різних регіонах країни по-різному), а в Чилі тарифи для проїзду у мікроавтобусах і таксі зросли вдвічі при збільшенні собівартості перевезень на 20\%.

Значною мірою це пояснюється особливостями реформ. У Коломбо була збережена державна автобусна компанія 3 дуже низькими тарифами. Щоб не втратити пасажирів, приватні перевізники теж були змушені підтримувати низькі тарифи. У Чилі зростанню тарифів сприяло обмеження конкуренції завдяки об'єднанню перевізників в так звані «маршрутні асоціації», тобто фактично завдяки «змові» перевізників.

У Великобританії тарифи зросли в середньому на 25\% протягом післяреформеного року і ще на $10 \%$ - наступного року. При цьому найбільше зростання тарифів сталось в регіонах, де вони до реформи підтримувалися на дуже низькому рівні за рахунок великих бюджетних субсидій. В цілому оцінка результатів реформи пасажирського автотранспорту у Великобританії викликала найбільшу дискусію, і думки експертів досить суперечливі [9, с. 35].

В країнах приватизація i скасування регулювання пасажирського автомобільного транспорту рідко супроводжуються збереженням значних прямих бюджетних субсидій. Помірна допомога іноді надається, наприклад, у формі обладнання автобусних зупинок або звільнення від податку на паливномастильні матеріали. Однак субсидії, раніше одержувані державними компаніями, при передачі цих компаній у приватний сектор зазвичай повністю скасовуються (оскільки саме навантаження на бюджет є важливим аргументом на користь приватизації). Якщо прямі субсидії зберігаються, вони надаються лише державній компанії, яка не розформовується, а працює в умовах конкуренції з приватними перевізниками.

На думку експертів, субсидування державних компаній в змішаній системі може мати сенс лише в рідкісних випадках, коли ці компанії застосовують 
набагато нижчий тариф або пропонують сервіс, що не надається приватними перевізниками [3, с. 181]. Однак навіть при наявності різних рівнів обслуговування і вартості проїзду збереження субсидій має серйозні мінуси. Головна проблема в тому, що якість обслуговування субсидованими автобусними компаніями залишається низькою за спільної дії двох чинників: високих витрат у державних компаніях і нездатності чи небажанні влади субсидувати розширення сфери і якість обслуговування.

У промислово розвинених країнах основна форма залучення приватних перевізників до надання транспортних послуг - це укладання контрактів на обслуговування регулярних автобусних маршрутів або на виконання окремих видів транспортних послуг (наприклад, перевезення школярів). При цьому приватним перевізникам можуть надаватися (як правило, на конкурсній основі) бюджетні субсидії. Згідно з даними, отриманими в результаті аналізу досвіду Великобританії (з укладення контрактів на транспортне обслуговування в Лондоні) i США (дані про контракти семи громадських агентств на обслуговування регулярних маршрутів у ряді штатів), собівартість транспортних послуг за контрактом на 20-30\% менше, ніж тих же послуг, що надаються місцевою муніципальною автобусною компанією.

Проведення ринкових реформ на пасажирському автотранспорті виявляється більш складним процесом. У великих містах США та Європи основні транспортні компанії перейшли у державну власність ще в кінці 60-х рр. XX ст., і частка субсидій складає в даний час в США $60 \%$, а в багатьох європейських країнах - більше $50 \%$ сумарних витрат транспортних компаній [6, c. 223].

Якщо для розвинених країн ці витрати не є катастрофічними, то в країнах, що розвиваються, проблема стоїть більш гостро. Автобусний транспорт там виконує значно більшу частку перевезень, тому питання державного регулювання тарифів 3 метою підтримання низької плати за проїзд набуває політичного значення.

Так, при вивченні досвіду роботи автомобільного транспорту Нідерландах та Німеччини [11, с. 245], законом про ліцензування передбачені тільки якісні обмеження. В першу чергу - це репутація власника транспорту, яка підтверджується мерією, свідоцтвом про благонадійність. Професійна придатність і фінансова стабільність, визначаються відповідно міністерствами транспорту і фінансів. У цих країнах закони про ліцензування визначають правила конкуренції, передбачають жорсткий контроль за виконанням законодавства, правил руху і норм роботи водія.

Застосовуються у світовій практиці і багато інших засобів, якими держава проводить свою транспортну політику в інтересах суспільства.

Корисним видається вивчення досвіду реформування громадського транспорту в Нідерландах [2, с. 59]. Закон про пасажирський транспорт, який набрав чинності 1 січня 2001 р., створив законодавчу базу для низки змін у функціонуванні громадського транспорту, в організації автобусних перевезень приватними компаніями і автобусних маршрутів, що з'єднують аеропорти 3 містами.

До 1 січня 2003 р. 35\% підприємств громадського транспорту Нідерландів 
в ході реформи було обрано за результатами тендерів. Виняток зробили для муніципальних транспортних маршрутів, за якими крайній термін був встановлений 1 січня 2006 р. Муніципальній владі дано додатковий час, щоб приватизувати транспортні компанії, багато з яких знаходяться в їх власності.

Оцінка результатів реформування після виставлення маршрутів на тендер повинна проводитись за наступними критеріями: збільшення величини пасажиро-кілометрів; підвищення якості обслуговування пасажирів; збереження плати за проїзд на тому ж рівні або ії зниження; зміна компенсації транспортним компаніям; підвищення безпеки і поліпшення умов роботи для персоналу; збереження робочих місць; гарантована доступність транспортних послуг.

Рішення на користь системи тендерів спричинило за собою виставлення до 1 січня 2006 р. на тендер всіх транспортних маршрутів, за винятком внутрішньо муніципальних. Перед автотранспортом країни поставлено також концептуальна завдання: на міських і регіональних транспортних маршрутах конкуренція вводиться тільки після того, коли постачальники транспортних послуг стануть незалежними від влади.

Транспортні компанії в Амстердамі, Роттердамі, Гаазі, Утрехті, Дордрехті, Неймегені i Маастріхті все ще $\epsilon$ частково або повністю власністю муніципалітету. За законом про пасажирський транспорт приватизація не обов'язкова. А місцевій владі, вибираючи транспортну компанію для обслуговування маршруту, недоцільно виступати одночасно в якості власника компанії. Тому саме муніципальні транспортні компанії повинні приватизуватися якомога швидше.

У своєму огляді С. Цимбал [10] відзначає, що в США і Великобританії 3 традиційно ринковою економікою накопичено величезний досвід застосування різних методів регулювання, пройдено шлях від експлуатації державного втручання до реалізації, в останнє десятиліття, програм максимального дерегулювання ринку транспортних послуг. Подібні в цілому процеси мали місце і в інших розвинених країнах, перш за все в Свропі. Однак, в них роль держави була і залишається важливішою, незважаючи на прийняття і реалізацію концепції дерегулювання.

Досвід США і Великобританії у багатьох відношеннях унікальний, і його неможливо повністю застосувати в Україні. Проте, можна знайти багато корисного в їх досвіді, особливо, якщо вдасться уникнути помилок і перейняти заходи, які довели свою ефективність.

При формуванні системи державного регулювання автомобільного транспорту Україні слід враховувати наступні обставини:

Вантажні автоперевезення $є$ ідеальною областю для проведення дерегулювання доступу в галузь обслуговування і тарифів. Економіка вантажних автоперевезень за своєю природою така, що в умовах конкуренції ефективність роботи і врахування потреб клієнтів забезпечуються значно надійніше, ніж 3 допомогою регулювання, необхідного тільки для ліцензування в цілях безпеки та дотримання професійних вимог.

Економічне регулювання $\epsilon$ досить ефективним засобом залучення приватного сектора до виконання державних завдань. Коли підприємство або істотна частина капіталу знаходиться у власності держави, слід домагатися 
максимальної комерціалізації їх діяльності. Надмірна участь відповідного відомства у регулюванні діяльності державного підприємства буде приводити до дуже небажаних результатів, так як неодмінно виникає конфлікт інтересів між об'єктивним проведенням політики і можливим впливом діяльності даного підприємства на державний бюджет. Відомства не можуть часом встояти перед спокусою політичної гри за рахунок бюджету.

При оцінці результатів дерегуляції у США і Великобританії нерідко упускається 3 уваги важливість того факту, що споживачі автотранспортних послуг у цих двох країнах очевидно діють з усвідомлених і передбачуваних економічних мотивів, в першу чергу, мінімізації витрат і максимізації прибутку. Однак, це навряд чи можливо зараз в Україні. Без відповідних змін організаційної структури і системи стимулювання споживачів транспортних послуг, дерегулювання за моделлю США і Великобританії може дати не передбачувані i навіть зворотні результати. Реорганізація структури i дерегулювання повинні проводиться паралельно 3 формуванням ринкового середовища в інших секторах економіки, що обслуговуються транспортом [11].

Аналіз ситуацій у багатьох зарубіжних країнах змушує зрозуміти, що не може бути успішною окрема «транспортна реформа». Транспортна політика та відповідна їй система регулювання транспорту можуть бути успішно змінені тільки після ініціювання реформ в інших областях: насамперед реформи устрою державних підприємств, бюджетної реформи (реформи державного фінансування) і реформи ринку праці.

Так, успіх реформи міського транспорту в Новій Зеландії був забезпечений сукупним ефектом багатьох інших реформ [4, с. 34]:

У 1988 був прийнятий Закон Про державні підприємства, що передбачає акціонування держпідприємств за моделями приватного сектора.

У 1988 р. був прийнятий Закон про держсекторі, змінив структуру управління новозеландських державних компаній.

У 1987 р. був прийнятий Закон Про трудові відносини, який істотно лібералізував цю сферу.

В 1989 р. був прийнятий Закон про громадські фінансах, який встановив систему звітності по продуктивності і результативності між урядом та міністерствами.

У 1990 р. був прийнятий Закон про зайнятість, який забезпечив ще більшу свободу праці - заборонив вимагати обов'язкове членство у профспілках для працівників i дозволив приватним i державним роботодавцям вибирати профспілки.

Втім, темп реформ у Новій Зеландії істотно сповільнилося в останні десять років тому більшість цих «загально реформаторських» досягнень Нової Зеландії вже істотно перекриті іншими країнами, зокрема, деякими країнами членами Організації Економічного Співробітництва та Кооперації [4, с. 36].

Транспортна політика за останні двадцять років зазнала змін у багатьох країнах через усвідомлення феномену «транспортної бюджетної діри» розуміння того, що бюджетних грошей ніколи не вистачить, щоб країна мала нормальний транспорт. Рано чи пізно слідом за націоналізацією і регулюванням настає стадія стагнації і спаду [3, с. 181]. Розвиток технологій, зростаючі обсяги 
перевезень і запити користувачів приходять у суперечність 3 інерційністю державної бюрократичної машини, низькою зацікавленістю менеджерів і власників в умовах безкоштовного або дешевого загального доступу (приклад так званої «трагедії громад» з економічної теорії).

В кінці XX ст. хронічний брак бюджетного фінансування знову привів більшість розвинених країн до необхідності залучення приватних інвестицій в інфраструктуру i, відповідно, до організації до неї платного доступу. Довелося, зокрема, визнати необхідність стягувати плату з користувачів будь-яких доріг, навіть побудованих на бюджетні гроші - треба відшкодовувати витрати, відтворювати наявні потужності і розвивати транспортну систему.

Укладання контрактів на транспортне обслуговування на конкурсній основі в зарубіжних країнах $\epsilon$ досить ефективним засобом створення конкуренції. Однак приватизація та інші форми залучення на ринок приватних перевізників мають важливу перевагу. Приватизований, не регульований і не субсидований сектор комерційних автобусних перевезень може служити важливим джерелом нововведень у транспортному обслуговуванні, спрямованих на надання транспортних послуг більш високої якості. Хоча скасування регулювання тарифів пов'язане з ризиком різкого подорожчання плати за проїзд, збереження регулювання може зменшити ефективність реформ.

Досвід реформ в зарубіжних країнах показує, що влада часто відчуває спокусу встановлювати нереально низькі тарифи для приватних автобусів, а це веде, як правило, до погіршення обслуговування. Крім того, при регулюванні тарифів їх часто прагнуть зробити простими і стандартними. Однак стандартні регульовані тарифи не заохочують або не дають можливості урізноманітнити послуги і не створюють стимулів до введення нововведень в обслуговуванні. Як правило, в ході реформування змінюється поділ ролей між державою і бізнесом - тому змінюються і структура, і функції регуляторів.

Міський транспорт, як правило, регулюється муніципальною владою, а часто і безпосередньо перебуває в іiі власності. На місцевому рівні транспортні влади представлені відділеннями державних відомств, що видають різноманітні ліцензії, та управліннями, які розпоряджаються державними або місцевими транспортними активами (портами, аеропортами, річковими i дорожніми системами, а також підприємствами міського транспорту). Управління мають необхідну владу по збору платежів та їх витрат, встановлення режиму роботи переданої їм в управління інфраструктури, а також є одержувачами бюджетних субсидій на розвиток інфраструктури.

Висновки $i$ перспективи подальших досліджень. Оцінюючи у цілому світовий досвід державного регулювання діяльності пасажирського автомобільного транспорту, можливо виділити наступні основні моменти. Поперше вигоди від реформ і скасування регулюючого впливу набагато зростають в тих випадках, якщо вдається створити і підтримувати сильну конкуренцію. Подруге тільки при наявності конкуренції приватизація дійсно може зменшити витрати і підвищити якість обслуговування. Без конкуренції такі реформи можуть не дати бажаного ефекту, погіршити обслуговування, а також викликати непередбачене зростання вартості проїзду i призвести до надмірності автобусного парку. По-третє у світі реформуються всі види транспорту, але 
особлива увага приділяється, міському та приміському транспорту як лідерам дотацій.

\section{Лimepamypa:}

1. Амоша O. I. Свропейський досвід забезпечення ефективного функціонування підприємств міського пасажирського транспорту. Економіка будівництва і міського господарства. 2010. № 4. Т. 6. С. 179-189.

2. Доброва Н. В., Осипова М. М., Нечепуренко М. С. Напрями удосконалення діяльності міського електротранспорту. Причорноморські економічні студіï. 2017. Вип. 14. С. 58 - 64.

3. Затонацька Т. Г. Розвиток транспортного сектору економіки України: існуючий стан та європейський досвід. Економіка: реалї часу. 2015. №1(17). C. $180-189$.

4. Казакова М. В. Реформа системы органов государственных власти в развитых странах: опыт США и Новой Зеландии : монография. Москва: [б. в.], 2015. $56 \mathrm{c}$.

5. Кучменко В. О. Зарубіжний досвід управління міським пасажирським транспортом в умовах сьогодення. Сучасні проблеми і шляхи їх розвитку в науці, mранспорті, виробництві та освіті 2011: матеріали Міжнар. наук.-практ. конф., (м. Одеса 20-27 груд. 2011 р.). Одеса: SWorld, 2011. С. 79 - 82.

6. Мороз О. Закордонний досвід організації транспортного обслуговування населення в містах. Економічний аналіз. 2013. Т. 12(1). С. 222 225.

7. Овчар П. А. Зарубіжний досвід державного регулювання у сфері транспортних послуг. Міжнародний науковий журнал "Інтернаука". 2017. № 6. C. $17-21$.

8. Поліщук В. П., Лановий О. Т., Сресов В. І., Куницька О. М., Корчевська А. А., Корчевський А. А. Моделювання умов небезпеки дорожнього руху для його учасників. Наукові нотатки. 2016. Вип. 55. С. 298 - 304.

9. Симпсон Б. Планирование развития городов и общественный транспорт в Великобритании, Франции и ФРГ [пер. с англ. ]. Москва: Транспорт, 2003. $96 \mathrm{c.}$

10. Цимбал С. В., Білик М. С. Зарубіжний досвід організації міських пасажирських перевезень. Матеріали XLV Науково-технічної конференції ВНТУ, (м. Вінниця, 23-24 березня 2016 р.). URL: http://conferences.vntu.edu.ua/ index.php/all-fmt/all-fmt-2016/paper/view/1216.

11. Шевчук Я. В. Зарубіжний досвід використання транспортних моделей в розвитку міських і сільських поселень. Науковий вісник Уэггородського університету: Серія: Економіка. Ужгород: УжНУ, 2013. Вип. 3(40). С. 244-252.

\section{References:}

1. Amosha O. I. (2010) Jevropejsjkyj dosvid zabezpechennja efektyvnogho funkcionuvannja pidpryjemstv misjkogho pasazhyrsjkogho transportu. Ekonomika budivnyctva i misjkogho ghospodarstva. no 4. vol. 6. pp. 179 - 189.

2. Dobrova N.V., Osypova M.M., Nechepurenko M.S. (2017) Naprjamy udoskonalennja dijaljnosti misjkogho elektrotransportu. Prychornomorsjki 
ekonomichni studiji. iss. 14. pp. $58-64$.

3. Zatonacjka T.Gh. (2015) Rozvytok transportnogho sektoru ekonomiky Ukrajiny: isnujuchyj stan ta jevropejsjkyj dosvid. Ekonomika: realiji chasu. no 1(17). pp. $180-189$.

4. Kazakova M.V. (2015) Reforma sistemy organov gosudarstvennykh vlasti v razvitykh stranakh: opyt SShA i Novoy Zelandii : monografiya. Moskva: [b. v.].

5. Kuchmenko V.O. (2011) Zarubizhnyj dosvid upravlinnja misjkym pasazhyrsjkym transportom v umovakh sjoghodennja. Suchasni problemy i shljakhy jikh rozvytku v nauci, transporti, vyrobnyctvi ta osviti 2011: materialy Mizhnar. nauk.prakt. konf., (m. Odesa 20-27 ghrud. 2011 r.). Odesa: SWorld, pp. $79-82$.

6. Moroz O. (2013) Zakordonnyj dosvid orghanizaciji transportnogho obslughovuvannja naselennja v mistakh. Ekonomichnyj analiz. vol. 12(1). pp. 222 225.

7. Ovchar P. A. (2017) Zarubizhnyj dosvid derzhavnogho reghuljuvannja u sferi transportnykh poslugh. Mizhnarodnyj naukovyj zhurnal "Internauka". no 6. pp. $17-21$.

8. Polishhuk V.P., Lanovyj O.T., Jeresov V.I., Kunycjka O.M., Korchevsjka A.A., Korchevsjkyj A.A. (2016) Modeljuvannja umov nebezpeky dorozhnjogho rukhu dlja jogho uchasnykiv. Naukovi notatky. iss. 55. pp. $298-304$.

9. Sympson B. (2003) Planyrovanye razvytyja ghorodov y obshhestvennыj transport v Velykobrytanyy, Francyy y FRGh [per. s anghl. ]. Moskva: Transport.

10. Cymbal S. V., Bilyk M. S. Zarubizhnyj dosvid orghanizaciji misjkykh pasazhyrsjkykh perevezenj. Materialy XLV Naukovo-tekhnichnoji konferenciji VNTU, (m. Vinnycja, 23-24 bereznja 2016 r.). available at: http://conferences.vntu.edu.ua/ index.php/all-fmt/all-fmt-2016/paper/view/1216.

11. Shevchuk Ja. V. (2013) Zarubizhnyj dosvid vykorystannja transportnykh modelej $\mathrm{V}$ rozvytku misjkykh i siljsjkykh poselenj. Naukovyj visnyk Uzhghorodsjkogho universytetu: Serija: Ekonomika. Uzhghorod: UzhNU. iss. 3(40). pp. 244-252.

As a result of today's transformations in the field of Ukrainian passenger road transport, of particular interest is the experience of state regulation of transport of countries that have already gone through significant reforms of urban transport in the United States, the United Kingdom, the Netherlands, Germany, New Zealand, etc. In these and other countries of the world, the problems of improving the efficiency of state and municipal regulation of passenger transport are in the center of public attention. One of the most discussed ways to solve these problems is the liberalization of the transport industry, its liberation from state regulation, which limits the scope of the market and free enterprise. The popularity of the market approach is largely due to the fact that government regulation of transport creates much more serious problems than those for which it was introduced.

The purpose of the article is to determine the features of foreign experience of state regulation of passenger road transport and identify certain tools that are appropriate to use in the formation of the system of state regulation of this process in Ukraine. 
First of all, we should mention the shortage of transport services, which arises from the fact that the state seeks to make the price of these services lower than the price of market equilibrium. The tariff set by the state is usually so low that the demand for transport services exceeds the supply. A special case is the zero tariff that we face when using free roads. The shortage of transport services is manifested in the congestion of transport infrastructure, lack of vehicles, queues, traffic jams. This phenomenon exists in almost all industrialized countries.

The shortage of transport services can be combined with high tariffs if a state monopoly is established. In order to establish a monopoly, it is sufficient for the government to prohibit or significantly restrict the entry of new service providers into certain markets. Especially often the state monopoly is established on transport infrastructure. This situation is typical for Japan and the European Union. A relaxed form of state monopoly is the strict licensing and restriction of entry to the market of transport services.

Assessing the global experience in the use of market mechanisms in passenger road transport, we can highlight the following main points. The benefits of reform and deregulation are much greater if strong competition can be created and maintained. Only in the presence of competition can privatization really reduce costs and improve the quality of service. Without competition, such reforms may not have the desired effect, worsen services, and cause an unexpected increase in the cost of travel and lead to redundancy of the bus fleet.

The conclusion of contracts for transport services on a competitive basis in foreign countries is quite an effective means of creating competition. However, privatization and other forms of attracting private carriers to the market have an important advantage. The privatized, unregulated and non-subsidized commercial bus sector can be an important source of innovation in transport services aimed at providing higher quality transport services. While deregulation of tariffs carries the risk of a sharp rise in fare prices, continued regulation may reduce the effectiveness of reforms. 